\title{
Transdifferentiation of Glioblastoma Stem-Like Cells into Mural Cells Drives Vasculogenic Mimicry in Glioblastomas
}

\author{
Steve Scully, ${ }^{1,2}$ Ralph Francescone, ${ }^{2}$ Michael Faibish, ${ }^{2}$ Brooke Bentley, ${ }^{1}$ Sherry L. Taylor, ${ }^{4}$ Dennis Oh, ${ }^{4}$ Robert Schapiro, ${ }^{4}$ \\ Luis Moral, ${ }^{5}$ Wei Yan, ${ }^{1}$ and Rong Shao ${ }^{1,2,3}$ \\ ${ }^{1}$ Pioneer Valley Life Sciences Institute, University of Massachusetts, Amherst, Springfield, Massachusetts 01107, ${ }^{2}$ Molecular and Cellular Biology Program, \\ Morrill Science Center, and ${ }^{3}$ Department of Veterinary and Animal Sciences, University of Massachusetts, Amherst, Amherst, Massachusetts 01003, and \\ Departments of ${ }^{4}$ Neurosurgery and ${ }^{5}$ Pathology, Baystate Medical Center, Tufts University, Springfield, Massachusetts 01199
}

Recent evidence has shown that glioblastoma stem-like cells (GSCs) can transdifferentiate into endothelial cells and vascular-like tumor cells. The latter pattern of vascularization indicates an alternative microvascular circulation known as vasculogenic mimicry (VM). However, it remains to be clarified how the GSC-driven VM makes a significant contribution to tumor vasculature. Here, we investigated 11 cases of glioblastomas and found that most of them consisted of blood-perfused vascular channels that coexpress mural cell markers smooth muscle $\alpha$-actin and platelet-derived growth factor receptor $\beta$, epidermal growth factor receptor, and vascular endothelial growth factor receptor 2 (Flk-1), but not CD31 or VE-cadherin. This microvasculature coexisted with endothelial cell-associated vessels. GSCs derived from patients with glioblastomas developed vigorous mural cell-associated vascular channels but few endothelial cell vessels in orthotopic animal models. Suppression of Flk-1 activity and gene expression abrogated GSC transdifferentiation and vascularization in vitro, and inhibited VM in animal models. This study establishes mural-like tumor cells differentiated from GSCs as a significant contributor to microvasculature of glioblastoma and points to Flk-1 as a potential target for therapeutic intervention that could complement current anti-angiogenic treatment.

\section{Introduction}

Tumor vasculature is typically assumed to arise from endothelial cell origin (Folkman, 1971). However, recent discoveries suggest an alternative mechanism whereby microvascular circulation is derived from tumor cells through a process known as vasculogenic mimicry (VM) (Maniotis et al., 1999). Evidence suggests that this matrix-embedded, blood-perfused microvasculature plays a vital role in tumor development, independent of endothelial cell angiogenesis. For example, highly aggressive melanoma cells generate numerous matrix-rich patterned channels containing blood cells, and the formation of these channels positively correlates with a worse prognosis for patients (Hendrix et al., 2003; Folberg et al., 2006). A mosaic model consisting both of tumor cell and endothelial cell-integrated networks was also described in the development of colon cancer (Chang et al., 2000). The presence of tumor-derived vasculatures highlights the plasticity of tumor cells and suggests involvement of cancer stem cells.

\footnotetext{
Received April 26, 2012; revised July 5, 2012; accepted July 25, 2012.

Author contributions: R.F. and R. Shao designed research; S.S., R.F., M.F., B.B., W.Y., and R. Shao performed research; S.S., R.F., S.L.T., D.O., R. Schapiro, L.M., and R. Shao analyzed data; R. Shao wrote the paper.

This work was partially supported by National Cancer Institute Grant R01 CA120659 (R. Shao). We are grateful to Drs. Mary Hendrix, Alonzo Ross, D. Joseph Jerry, Lawrence Schwartz, and Lisa Minter for their critical comments. We also thank Dr. Geet de Vries for help of intracranial injection and Narvis Handford, RN, for her assistance in patients' consenting in the sample collection.

The authors declare no competing financial interests.

Correspondence should be addressed to Rong Shao, Pioneer Valley Life Sciences Institute, University of Massachusetts, Amherst, 3601 Main Street, Springfield, MA 01199. E-mail: rong.shao@bhs.org.

DOI:10.1523/JNEUROSCI.2017-12.2012

Copyright $\odot 2012$ the authors $\quad 0270-6474 / 12 / 3212950-11 \$ 15.00 / 0$
}

Glioblastomas, the most lethal primary brain tumor, display an extensive vasculature phenotype which is highly correlated with aggressiveness (Wen and Kesari, 2008). Glioblastoma stem cells (GSCs) that possess self-renewing and differentiation properties have been found to be associated with malignancy of this disease (Singh et al., 2004; Beier et al., 2007). Furthermore, GSCs are capable of transdifferentiation into vascular endothelial cells that participate in angiogenesis (Ricci-Vitiani et al., 2010; Wang et al., 2010) and vessel-like tumor cells that also involve VM (El Hallani et al., 2010). However, it has not been thoroughly characterized whether this GSC-derived VM represents a significant component of microvasculature, and how GSCs transdifferentiate into vessel-like cells that mediate vasculogenesis of glioblastomas. Thus, it is emerging that elucidation of these vascularized events will offer new mechanistic insights into the malignancy of glioblastomas that are commonly characterized by tumor angiogenesis. In addition, it is noteworthy that recent clinical trials have demonstrated a minimal overall benefit of anti-angiogenic monotherapy (e.g., an anti-VEGF antibody bevacizumab) to patient survival (Bergers and Hanahan, 2008; Verhoeff et al., 2009). Therefore, investigation of GSC-derived VM will complement current therapeutic strategies that mainly focus on inhibition of endothelial cell angiogenesis. Here, we discovered that GSCs primarily transdifferentiate into vascular mural-like cells, to develop VM, a process dependent on VEGF receptor 2 (Flk-1).

\section{Materials and Methods}

Neurospheres. Tumor samples were obtained from consenting patients with glioblastoma as approved by Baystate Medical Center Institutional 
Review Board. Glioblastoma tissue was enzymatically digested, and stem cell spheres were generated as previously described (Galli et al., 2004). These GSCs were propagated over 50 passages without senescence in stem cell medium DMEM/F12 supplemented with B27 (Invitrogen) and $20 \mathrm{ng} / \mathrm{ml} \mathrm{bFGF}$ and EGF. GSCs between passages 5 and 10 were used in this study.

Differentiation of GSCs. For multipotent lineage differentiation, GSCs were plated on $0.25 \mathrm{mg} / \mathrm{ml}$ poly-L-ornithine-coated dishes in growth factor-free stem cell medium with B27 and 1\% FBS for 1 week. For serum-induced differentiation, GSCs were grown in 10\% FBS DMEM for 1 week. For endothelial cell differentiation, GSCs or CD $133^{\text {high }}$ GSCs were grown in EBM-2 basal medium kit (Lonza) supplemented with 5 ng/ml VEGF.

Immunoprecipitation and immunoblotting. The samples were processed as described previously (Shao et al., 2009). Cell lysates were immunoprecipated with an anti-pY20 monoclonal antibody (ICN Biomedicals) followed by immunoblotting against Flk-1 (Santa Cruz). For immunoblotting, primary antibodies included CD31, Tie1, Tie2, green fluorescent protein (GFP), Flk-1 (Santa Cruz), smooth muscle $\alpha$-actin (SMa) (Abcam), Laminin5- $\gamma 2$ (Millipore Bioscience Research Reagents), VE-cadherin (VE-cad) (Invitrogen), epidermal growth factor receptor (EGFR) (Cell Signaling), and actin (Sigma-Aldrich) antibodies.

Immunocytochemistry. The method was described previously (Yan et al., 2010). Antibodies included Nestin (Millipore), CD133 (Abcam), glial fibrillary acidic protein (GFAP) (Dako), $\beta$-Tubulin-III, Gal C (Millipore Bioscience Research Reagents), NG2 (Millipore), and SMa (Dako). Dual staining was performed by sequential staining of one protein followed by another.

Flk-1 gene knockdown. A PGPU6-GFP-neo shRNA expression vector containing DNA oligos (21 bp) (GenePharma) specifically targeting 5' -GCATCAGCATAAGAAACTTGT-3' (shRNA1), 5' -GCTTTACTATTCCCAGCTACA-3' (shRNA2), 5'-GGAATTGACAAGACAGCAACT-3' (shRNA3), 5'-GCTTGGCCCGGGATATTTATA-3' (shRNA4) of Flk-1, or 5'-TTCTCCGAACGTGTCACGT- $3^{\prime}$ as a non-sense control were transfected into GSCs using Fugene 6. Cells were selected in $800 \mu \mathrm{g} / \mathrm{ml} \mathrm{G} 418$ starting $48 \mathrm{~h}$ after transfection, and GFP expression was monitored to evaluate transfection efficiency.

Magnetic cell sorting and flow-cytometric analysis. Magnetic cell separation and sorting based on CD133 expression were performed according to the instruction of a CD133-labeling MicroBeads kit (Miltenyi Biotec), and expression of CD133 was analyzed by flow cytometry analysis using FACScan.

Tube formation and immunofluorescence. Tubule formation was performed as described previously (Shao et al., 2009). For immunofluorescence staining, tubules were fixed with $2 \%$ paraformaldehyde and permeabilized with $0.5 \%$ Triton X-100 followed by incubation with antiGFAP, $\beta$-Tubulin III, Gal C, Flk-1, and SMa antibodies, and secondary Alexa Fluor 488 and 555 antibodies as described above (see Immunocytochemistry).

Animal models. All animal experiments were performed with the approval of Institutional Animal Care and Use Committee of the University of Massachusetts and Baystate Medical Center. GSCs expressing Flk-1 shRNA or scramble RNA $\left(50 \times 10^{3}\right.$ cells $/ 5 \mu \mathrm{l}$ of PBS $)$ were injected into right striatum of SCID/Beige mice. Mice were killed when mice displayed decreased locomotion.

Immunohistochemistry and immunofluorescence. The procedure for tissue immunohistochemistry (IHC) was described previously (Shao et al., 2009). Antibodies included mouse anti-hCD31 (1:100), hCD34 (1:200), and SMa (1:500) (Dako) antibodies, rat anti-mCD31 (1:100; BD Biosciences), or rabbit anti-Flk-1 and platelet-derived growth factor receptor $\beta$ (PDGFR $\beta$ ) (1:200; Santa Cruz) antibodies. Dual immunohistochemistry labeling was performed using a sequential process of one antibody staining followed by another staining. For a single and dual immunofluorescent staining, tumor specimens were incubated with a mouse antihCD31, SMa, or a rat anti-mCD31 antibody for $2 \mathrm{~h}$ followed by incubation with a goat anti-mouse Alexa Fluor 488 secondary antibody (1:250) for $1 \mathrm{~h}$. Then the samples were similarly incubated with a rabbit anti-PDGFR $\beta$ or Flk- 1 antibody, or a mouse hCD31 followed by incubation with a goat anti-rabbit Alexa Fluor 555 antibody. Finally, 4',6diamidino-2-phenylindole (DAPI) (Invitrogen) was added to stain
Table 1. Different cell lineage markers

\begin{tabular}{ll}
\hline Endothelial progenitor marker & CD34 \\
Endothelial cell markers & CD31/PECAM-1 \\
& CD34 \\
& VE-cad \\
& CD34 \\
& Tie1 \\
& Tie2 \\
Vascular mural cell markers & SMa \\
& NG2 \\
GSC markers & PDGFR \\
& CD133 \\
GSC neural differentiation markers & Nestin \\
Astrocyte marker & \\
Neuron marker & GFAP \\
Oligodendrocyte marker & $\beta$-tubulin III \\
\hline
\end{tabular}

nucleus. NIH ImageJ software was used to quantify vessel density in the single staining of CD31, SMa, or PDGFR $\beta$ in IHC, and double immunofluorescent staining of CD31 with SMa or PDGFR $\beta$.

Fluorescent in situ hybridization. Fluorescent in situ hybridization for EGFR gene amplification in glioblastomas was performed according to the instruction of EGFR probe mix (Dako). Tissue samples were incubated with a Texas Red-labeled DNA probe that binds to the EGFR gene on chromosome $7 \mathrm{q} 11.2$ overnight in a humid chamber at $45^{\circ} \mathrm{C}$. Following posthybridization washes, slides were counterstained with DAPI.

Statistics. Data are expressed as mean $\pm \mathrm{SE}$, and $n$ refers to the numbers of individual experiments performed. Differences among groups were determined using one-way ANOVA analysis followed by the Newman-Keuls test. The 0.05 level of probability was used as the criterion of significance.

\section{Results}

Glioblastomas harbor extensive tumor cell-lined, blood-perfused channels

To validate that VM occurs in glioblastoma, we distinguished potential tumor cell-associated vascular channels from endothelial cell-derived vessels using IHC of tumor samples from 11 cases of patients with glioblastomas. Staining with antibodies against CD31/PECAM-1 and VE-cad, mature endothelial cell markers in tumor tissue (Table 1) showed that CD31 and VE-cad-positive and -negative vessels containing blood cells were intermingled within the tissue (Fig. $1 a-c$ ). IHC with an anti-CD34 antibody, a marker for both endothelial progenitor cells and mature cells, also revealed that a large portion of vessels were negative for CD34 (Fig. 1d), suggesting a nonendothelial origin. Thus, the vessel staining indicates that a significant population of vascular cells but not endothelial cells constitutes blood vessels, which is negative for CD31, VE-cad, and CD34.

To discern whether mural cells participate in the formation of glioblastoma microvasculature, we costained for a mural cell marker SMa and CD31. In the 11 cancer patients, we found that most of these cases ( 7 cases) contained a large portion of strong SMa- and GFAP-positive vessels and a few vessels expressing CD31 (Fig. 1e-h). Two cases displayed moderate SMa-positive vessels and a high density of CD31-positive vessels (data not shown). The last two cases showed a minimal level of vessels, indicative of nonvascularized tumors. To validate that the component of these vessels was predominantly ascribed to mural-like cells, we used an immunofluorescent approach that is more sensitive than IHC in deciphering vasculature formed by endothelial cells, mural cells, or both cells. A dual immunofluorescent analysis of SMa and CD31 showed a significant vascular population positive for SMa but negative for CD31, coexisting with CD31- 

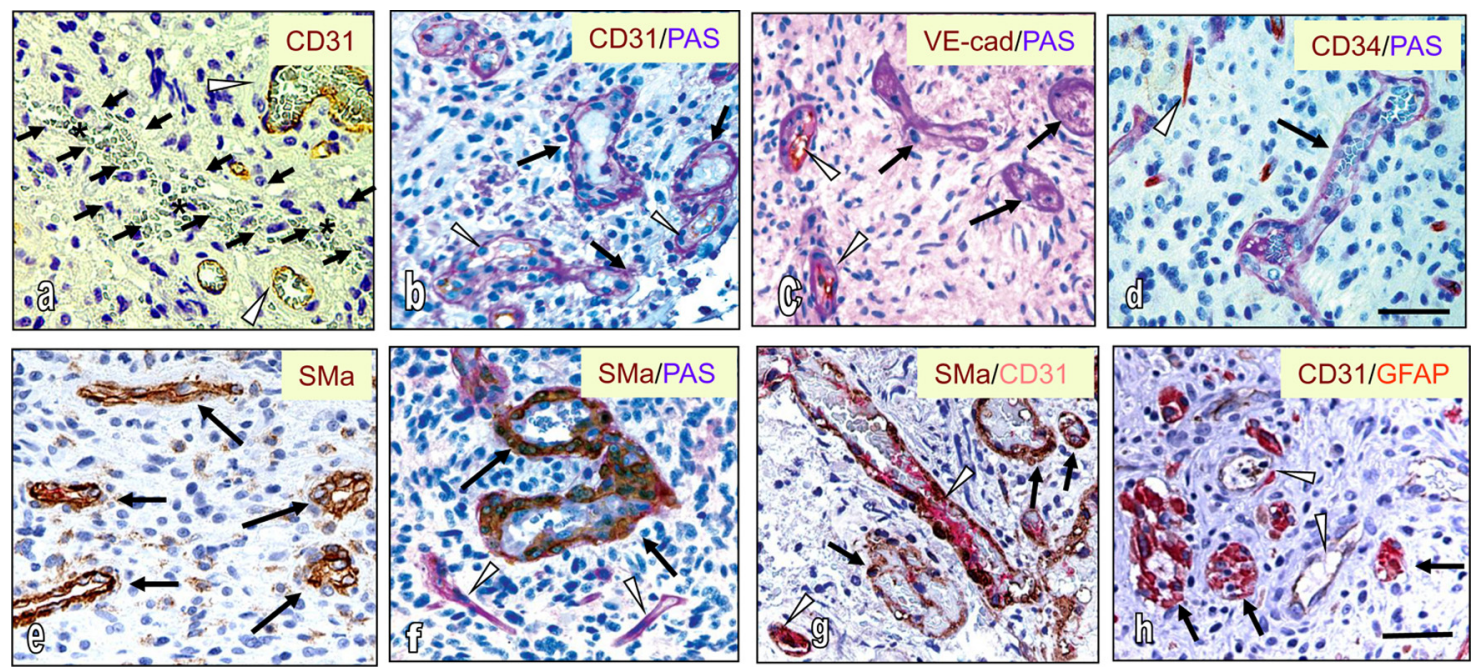

Figure 1. Extensive tumor cell-associated, blood-perfused channels coexist with endothelial cell-associated vasculature in glioblastoma. Tumor specimens were subjected to CD31 staining (a), costaining of CD31 with periodic acid-Schiff (PAS) (b), VE-cad with PAS (c), CD34 with PAS (d), SMa (e), SMa with PAS (f) , SMa with CD31 (g), and CD31 with GFAP (h). The arrows represent tumor cell-associated vascular channels in which blood cells are located, whereas the arrowheads indicate endothelial cell-associated vessels. Note CD31-negative (a) vascular channels delineated with a series of arrows contained blood cells (stars). Scale bars, $100 \mu \mathrm{m}$.

positive vessels (Fig. $2 A, B$ ). The quantification analysis of SMa and CD31 showed a majority (59.7\%) of vessels positive for SMa, $34.1 \%$ of vessels positive for CD31, and the rest (10.3\%) for both positive vessels (Fig. $2 C$ ). These results were also confirmed by the similar double staining with CD31 and PDGFR $\beta$, a vascular pericyte marker (Fig. $2 D, E$ ). These vessels were also positive for VEGF receptor 2 (Flk-1) (Fig. $2 F$ ), in which costaining of Flk-1 and SMa was observed (Fig. 2G). These results suggest that mural-like cells participate in VM, whereas endothelial cells are associated with tumor angiogenesis.

To determine whether these mural-like cells in these samples were derived from the tumor itself, we stained tissue sections with a fluorescent in situ hybridization probe specific for EGFR gene amplification as it is overexpressed by some populations of glioblastomas (Mischel et al., 2003; Heimberger et al., 2005; Jung et al., 2007; Feng et al., 2012). As shown in Figure 2 H, EGFR amplification, as depicted by multiple red hybridization signals, was detectable in some nuclei of the tumor cells. In addition, increased amplification of EGFR was found in the cells that constitute vessel wall (Fig. 2I). All the data suggest that these bloodperfused vascular channels consisted of mural-like tumor cells characteristic both of neural tumor cells and vessel wall cells.

\section{GSCs transdifferentiate into mural-like cells that coexpress markers of neural and vascular lineages}

To gain insight into a potential role for tumor stem cells in the development of VM, we isolated primary tumor cells from two patients with glioblastomas and cultured them in growth factorsupplemented stem cell medium. These cells exhibited properties of stem cells capable of self-renewing, growing as neurospheres, and expressing neural stem cell (NSC) markers Nestin and CD133 (Fig. 3A, Table 1), in which the $\mathrm{CD}_{133}{ }^{+}$population $(37 \%)$ or nestin ${ }^{+}$population $(28 \%)$ was enriched for these spheres, consistent with previous evidence of $\mathrm{CD} 133^{+}$population (Galli et al., 2004; Singh et al., 2004). To demonstrate the multipotency of the neurospheres, these stem-like cells were grown on ornithine-precoated plates in growth factor-free medium to differentiate into neural lineages. Immunocytochemical analyses showed that the primary population was composed of astrocytes $(80 \%)$ followed by neurons (15\%), and the remainder of cells were oligodendrocytes (less 5\%) (Fig. 3A). This multipotency was consistent with previous findings (Galli et al., 2004; Beier et al., 2007; Zheng et al., 2010), suggesting that GSCs recapitulate NSCs capable of differentiation into neural lineages. However, neither of the GSCs nor their neural differentiated lineages expressed SMa (see below), the marker that was highly expressed in vascular channels in glioblastoma.

To determine whether GSCs also possess the ability to transdifferentiate into cells distinct from their neural lineages, we transferred GSCs into regular culture dishes supplemented with $10 \%$ FBS, a differentiation condition described previously (Oishi et al., 2004; Lee et al., 2006; El Hallani et al., 2010). It was interesting to find that these serum-induced differentiated cells [defined as glioblastoma serum-differentiated cells (GSDCs)] did not favor the formation of any particular neural lineage derivatives, since all of the markers (GFAP, $\beta$-tubulin III, and Gal C) were equally expressed (42-50\%) in these cells (Fig. 3B). Furthermore, these cells expressed mural cell markers SMa and NG2 (Fig. $3 \mathrm{Ca}, b)$, and evenly coexpressed GFAP, $\beta$-tubulin III, Gal C, and SMa $(20-45 \%)$ (Fig. $3 C c-i)$. These unique capabilities of neural lineage differentiation and transdifferentiation were identically found in a separate GSDC line derived from a different patient with glioblastoma (data not shown). The data suggest the multipotency of GSCs able to differentiate into tumor cells that share genetic features of both neural and vascular lineages.

\section{GSDCs express mural cell markers and display a vascular phenotype}

To further evaluate that these mural-like cells are distinct from individual neural lineages and endothelial lineages, we performed immunoblotting to assess the expression of mural and endothelial cell markers. GSDCs expressed strong SMa, EGFR, and laminin $5 \gamma-2$, the extracellular matrix protein enriched in vascular channels (Fig. 4A) (Seftor et al., 2001). However, the other cell types, including human microvascular endothelial cells (HMVECs), GSCs, and their neural differentiated cells, expressed a lower level of SMa. Notably, GSDCs, like HMVECs, expressed Flk-1 at higher levels than the GSCs and their neural differentiated cells. In contrast to HMVECs, GSDCs did not express the endothelial cell-specific markers CD31, VE-cad, Tie1, or Tie2 
$\mathrm{SMa} / \mathrm{CD} 31 / \mathrm{DAP}$

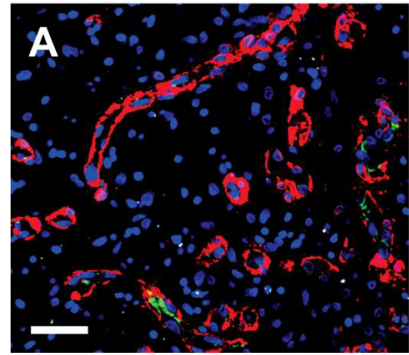

SMa/CD31/DAPI

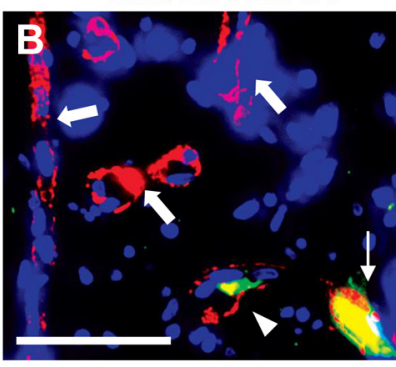

C

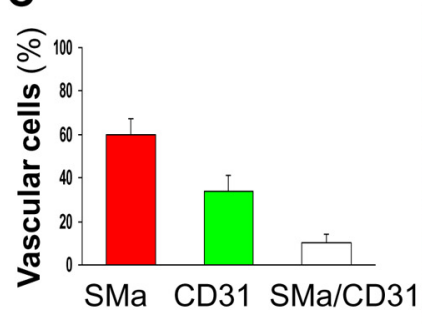

PDGFRB/CD31/DAPI

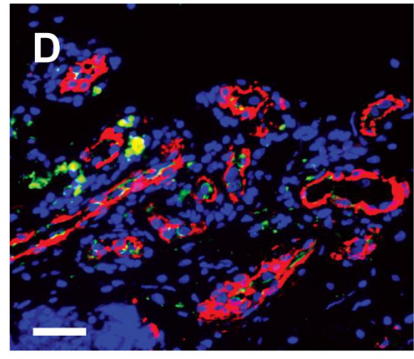

PDGFR $\beta / C D 31 / D A P I$

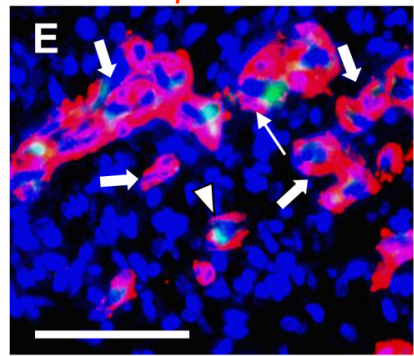

Flk-1

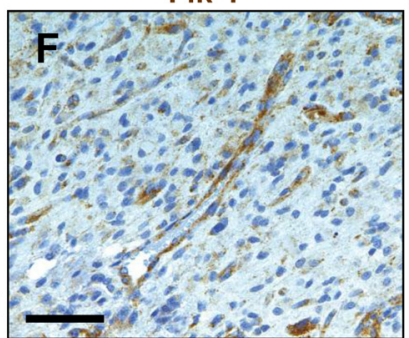

FIk-1/SMa/DAPI

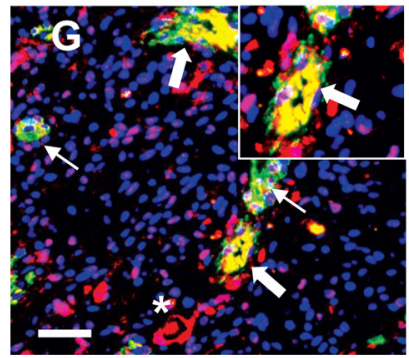

EGFR/DAP

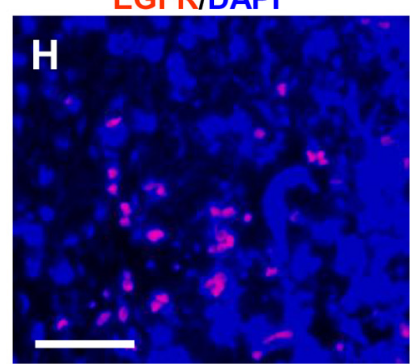

EGFR/DAPI

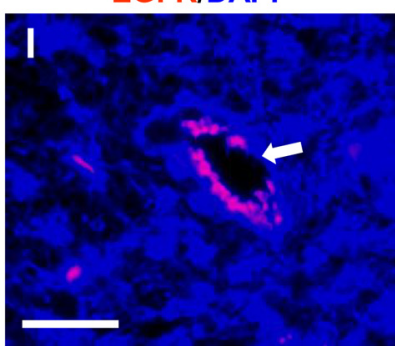

Figure 2. Tumor vessels consist of mural-like cells that coexpress SMa, PDGFR $\boldsymbol{\beta}$, Flk-1, and EGFR. Glioblastoma samples were subjected to coimmunofluorescent staining of SMa with CD31 ( $\boldsymbol{A}$, $\boldsymbol{B})$, and these vessels were quantified. The total of fluorescent vessels was set as $100 \% . n=7$. Error bars indicate SEM (C). Tumor samples were also used for coimmunofluorescent staining of PDGFR $\beta$ with CD31 $(\boldsymbol{D}, \boldsymbol{E})$. The thick arrows indicate SMa- or PDGFR $\beta$-positive vessels only, the thin arrows show CD31-positive vessels with a few SMa- or PDGFR $\beta$-positive cells, and the arrowheads depict a mosaic model containing most of SMa- or PDGFR $\beta$-positive cells with a few CD31-positive cells. $\boldsymbol{B}$ and $\boldsymbol{E}$ showed higher magnified images. Tumor samples were used for IHC of Flk-1 (F) and coimmunofluorescent staining of Flk-1 and SMa $(\boldsymbol{G})$. The thin arrows indicate SMa-positive vessels, and the thick arrows depict coexpression of SMa and Flk- 1 in which an inset shows a larger image. The stars show Flk-1-positive vessels only. Some of GBM samples were used to stain EGFR expression in nuclei via a fluorescent in situ hybridization EGFR probe (red). EGFR gene expression as multiple red signals was located in tumor nuclei $(\boldsymbol{H})$, and its higher amplification was found in vessel-associated tumor cells $(\boldsymbol{I})$. An arrow indicates a vessel. Images of detecting chromosome 7 copy number using a fluorescein-labeled PNA probe were not shown. Scale bars, $100 \mu \mathrm{m}$.

(Fig. 4A), unambiguously demonstrating that GSDCs are not endothelial cells.

Should GSDCs truly represent cells capable of developing vascular channels in vivo, they might possess the vasculogenic activity of endothelial cells. To test this hypothesis, we performed a tube formation assay that recapitulates the ability of endothelial cells to develop vasculature in vitro. GSDCs formed a capillary phenotype and coexpressed SMa, GFAP, $\beta$-tubulin III, Gal C, and Flk- 1 (Fig. 4 B). In contrast, GSCs as well as their neural differentiated cells failed to develop tubules regardless of cell density plated (Fig. 4B, C). To validate the abilities of GSCs to differentiate into mural cells and develop vasculature, we measured the expressions of these vascular markers in GSDCs from the second patient with glioblastoma. Analogous to the findings earlier, GSDCs from the second patient expressed SMa and Flk-1, but not CD31, Tie 1, and Tie 2 (Fig. 4D), and formed tubules in a cell number-dependent fashion, which underscores the plasticity of GSDCs able to form de novo vasculature. These data suggest that transdifferentiation of GSCs into mural-like GSDCs promotes vasculature formation.

We were also interested in the possible role played by the hierarchy of GSCs in the development of VM. Therefore, GSCs were sorted to select CD133-expressing cells. As seen by FACS analysis, neither the $\mathrm{CD} 133^{\text {high }}$ nor the $\mathrm{CD} 133^{\text {low }}$ cell populations formed tubules (Fig. $5 A, B$ ). These CD133 ${ }^{\text {low }}$ neurospheres did not show the ability to self-renew as they were senescent by 1-2 weeks. However, once sorted CD $133^{\text {low }}$ cells were immediately transferred to serum/DMEM-supplemented plates to drive transdifferentiation, they acquired the vascularized capability (tube formation) and proliferation similar to CD133 ${ }^{\text {high }}$-differentiated cells (data not shown). The results suggest that this vasculogenic property is dependent on GSC differentiation but not $\mathrm{CD}_{133^{+}}$or CD $133^{-}$-GSC population. To determine whether GSCs display the ability to transdifferentiation into vascular endothelial cells, we grew both GSCs and sorted CD133 ${ }^{\text {high }}$ GSCs in the endothelial cell culture medium (Ricci-Vitiani et al., 2010). After 2 week culture, these differentiated cells were measured for CD31, VE-cad, and SMa expression. Immunoblotting data revealed undetectable levels of CD31 and VE-cadherin, and low levels of SMa in GSC and CD133 ${ }^{\text {high }}$ GSC differentiated cells (Fig. 5C), consistent with FACS analysis on CD31 expressed by a small population $(<1.5 \%)$ (data not shown). All the data support our hypothesis that the majority of GSCs transdifferentiates into 


\section{A GSC}

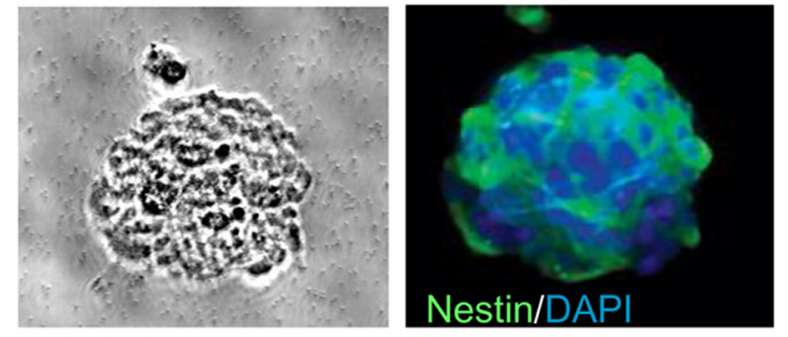

GSC neural differentiation
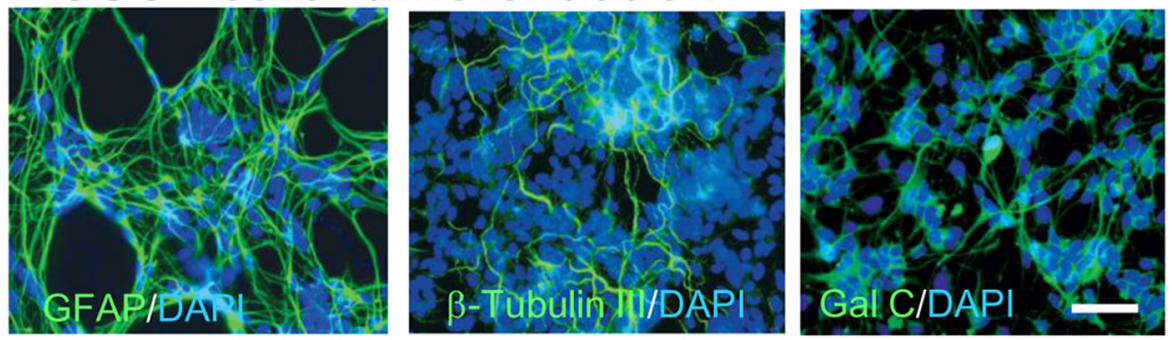
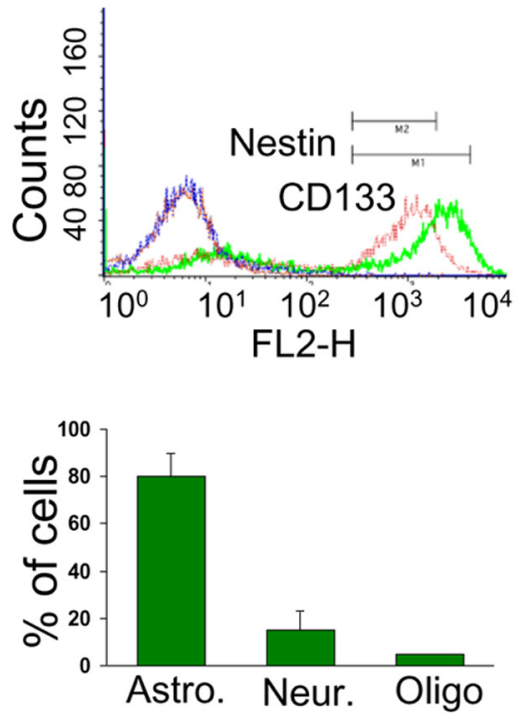

B

\section{GSDC}
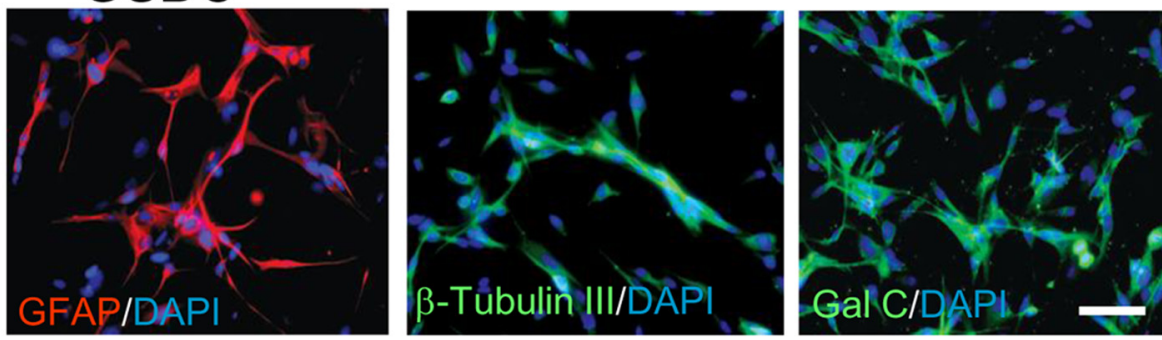

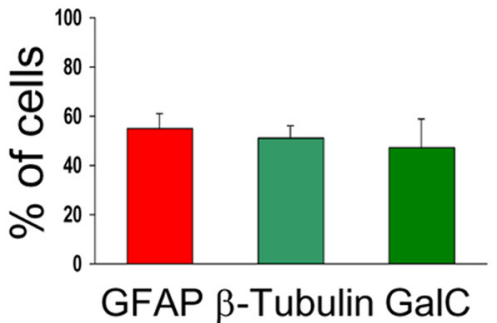

\section{C}

\section{GSDC}
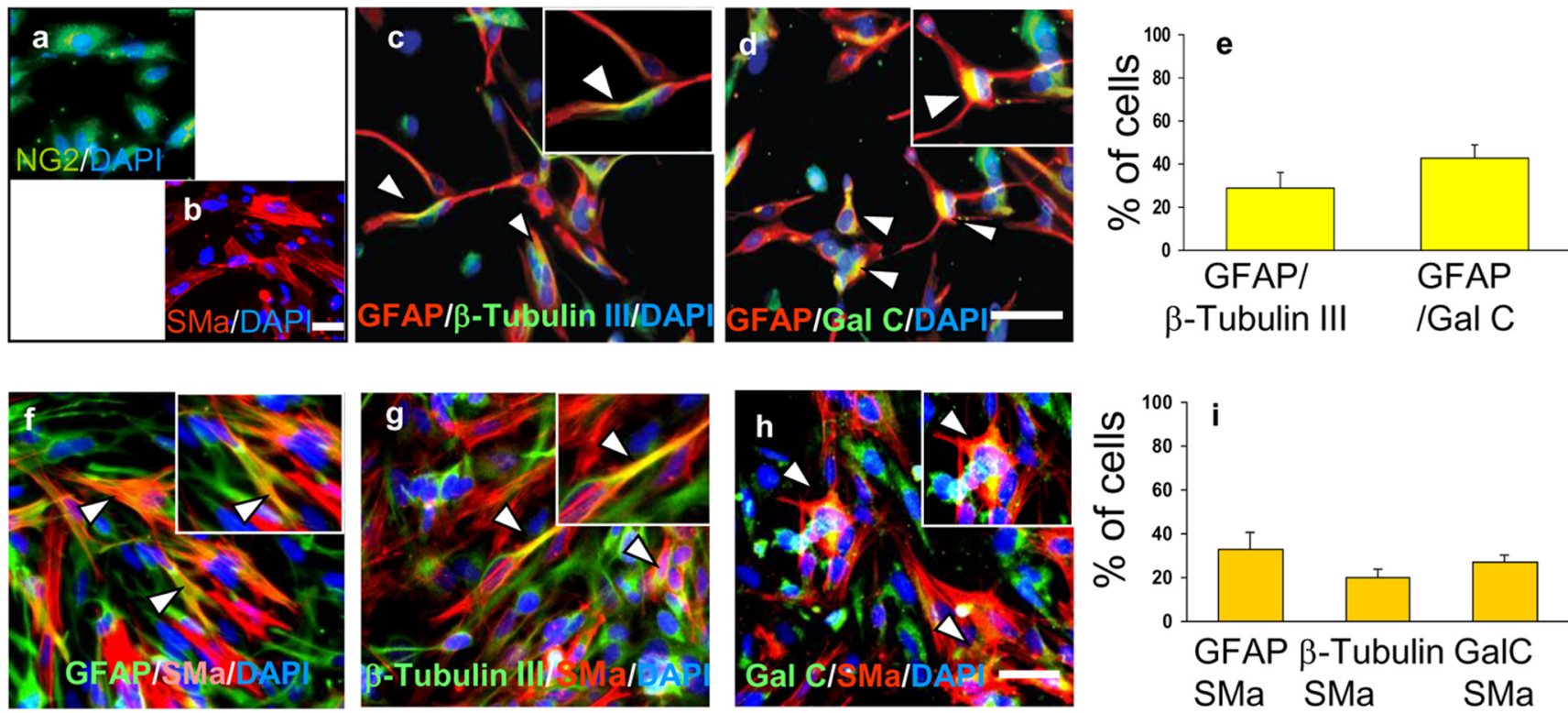

Figure 3. Differentiation of GSCs into neural lineages and mural-like cells. A, GSC neurospheres were stained for Nestin and CD133. A significant population of CD133 ${ }^{+}$GSCS was identified through FACS analysis. Neural differentiated cells from GSCs were stained for Gal C, $\beta$-Tubulin III, and GFAP. Each subtype of positive cells was quantified. B, GSDCs were analyzed and quantified for the neural lineage markers as indicated above. C, GSDCs were subjected to costaining of NG2 with DAPI (a), SMa with DAPI (b), GFAP with $\beta$-tubulin III and DAPI (c,e), GFAP with Gal C and DAPI (d, $\boldsymbol{e}$ ), and SMa with GFAP, $\beta$-tubulin III, or Gal C ( $\boldsymbol{f}$-i $)$. Double-positive staining cells were quantified by normalization with total cells set as $100 \%$. The arrowheads indicate overlapping images (c, $\boldsymbol{d})$, and the insets show larger images. Scale bars, $50 \mu \mathrm{m} . n=3$. Error bars indicate SEM. 


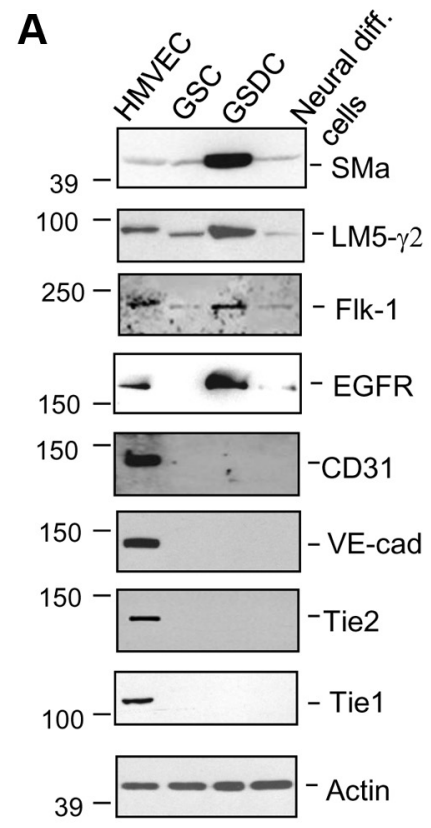

B

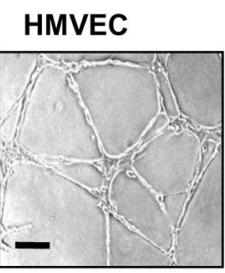

\section{GSDC}

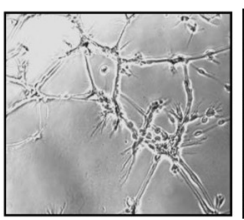

GSC

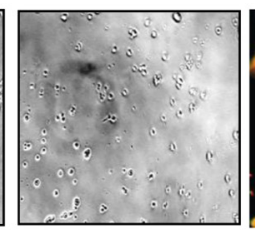

D

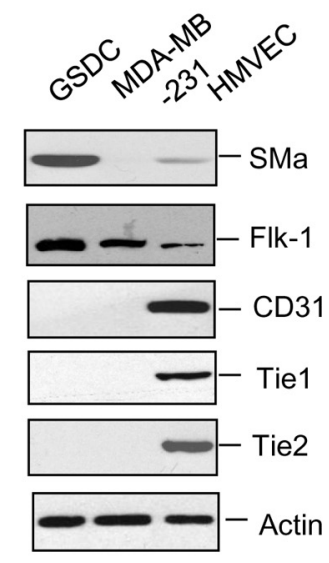

E

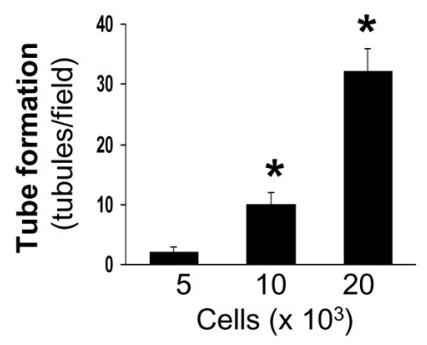

C

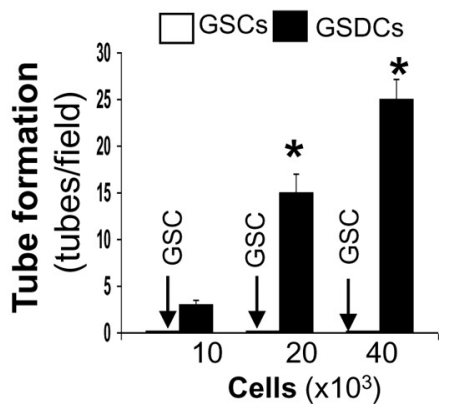

Figure 4. GSDCs do not express endothelial cell markers but are able to develop a vascular phenotype. $A$, Cell lysates of HMVECs, GSDCs, GSCs, and GSC neural-differentiated cells were analyzed by immunoblotting. $\boldsymbol{B}$, HMVECS, GSDCS, GSCS, and GSC neural-differentiated cells were assayed for tube formation as imaged in phase contrast, and then costained with antibodies specific for SMa, neural lineage markers, and Flk-1. The yellow images depict overlap of the staining. Scale bar, $50 \mu \mathrm{m}$. C, Different numbers of GSCs and GSDCs as indicated were selected for tube formation. $n=$ 3. ${ }^{*} p<0.05$ compared with tubules formed by 10,000 GSDCS. D, GSDCs derived from a different patient were measured for Flk-1, SMa, CD31, Tie 1, and Tie 2 expression. Breast cancer cells MDA-MB-231 were used for a negative control. E, These GSDCs from the second patient were tested for tube formation, showing higher potential of vascular capability than the cells derived from the first patient (C). Error bars indicate SEM.

mural-like tumor cells, whereas a small population undergoes endothelial cell transdifferentiation that mediates angiogenesis.

\section{Expression of Flk-1 is essential in GSC transdifferentiation and vascular formation}

Flk-1 is appreciated to mediate differentiation of embryonic stem cells into cardiac and vascular tissues including endothelial cells and mural cells (Yamashita et al., 2000; Yang et al., 2008; Taura et al., 2009). To test the hypothesis that Flk-1 is required for mural cell transdifferentiation of GSCs, we used a Flk-1 kinase inhibitor (E)-3-(3,5-diisopropyl-4-hydroxyphenyl)-2-[(3-phenyl- $n$-propyl) amino-carbonyl] acrylonitrile (SU1498). Treatment with SU1498 inhibited the ability of GSDCs to induce capillary-like structure by $\sim 80 \%$ relative to controls (Fig. 6 A). SU1498 also suppressed SMa expression. Furthermore, we treated GSCs with SU1498 before the introduction of serum-containing medium (Fig. 6B), and we found that transdifferentiation was decreased beginning as early as day 1 . These cells lost their ability to transdifferentiate and grow beyond day 3 , and were senescent by day 7 . In contrast, both control and DMSO-treated cells underwent differentiation and proliferation throughout the $7 \mathrm{~d}$ culture period. These data suggest that elevated expression of Flk-1 by GSCs is required for their transdifferentiation and inhibiting Flk-1 effectively prevents this event in vitro.

To further assess the active role played by Flk-1 in the development of a vascular phenotype of GSDCs, we used an Flk-1 shRNA gene knockdown approach in GSCs from two patients with glioblastoma. After introduction of four individual Flk-1 shRNA genes to GSCs, one of them (shRNA4) reduced expression of Flk-1 and SMa, and tyrosine phosphorylated form of Flk-1 as well during their transdifferentiation into GSDCs (Fig. $6 C)$. As a result, Flk-1 shRNA profoundly impaired their ability to develop tubules compared with scramble control GSDCs (Fig. 6D). The other three shRNAs (shRNA1-3) did not have effects on its expression (data not shown). The data support the notion that Flk-1 mediates mural-like cell transdifferentiation. 
A
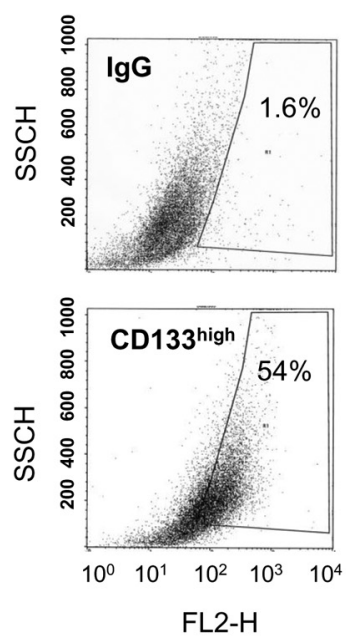

B
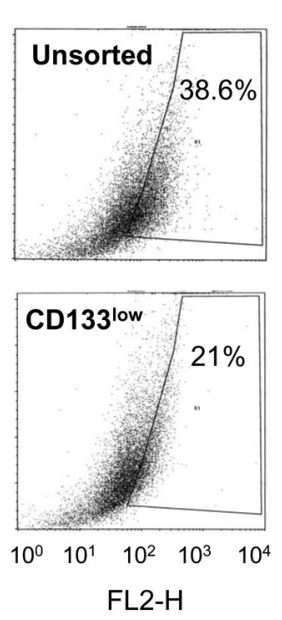

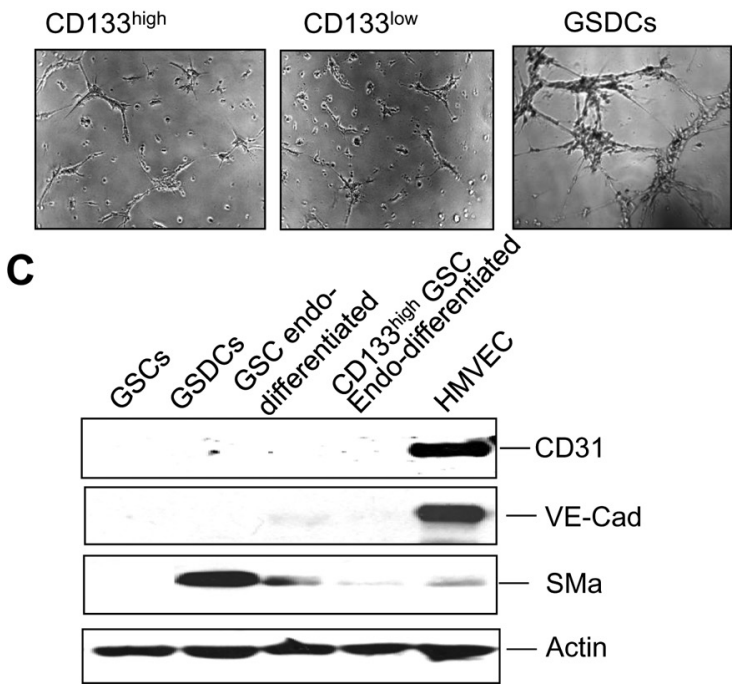

Figure 5. Subpopulation of CD133 ${ }^{\text {high }}$ and CD133 ${ }^{\text {low }}$ GSCs fail to induce tubules in Matrigel, and both GSC and CD133 ${ }^{\text {high }}$ population do not acquire expression of endothelial cell markers in endothelial cell culture medium. $\boldsymbol{A}$, GSCs were sorted for subpopulation of CD133 high and CD133 low cells using a magnetic cell separation system as described in Materials and Methods. $\boldsymbol{B}$, CD133 high and CD133 ${ }^{\text {low }}$ cells $\left(2 \times 10^{4}\right)$ were used for tube formation assay, but none of these two subtypes developed tubules. Tubules formed by GSDCs represented a positive control. C, GSC and CD133 high population were grown in endothelial cell medium for 2 weeks, and then cell lysates were measured for expression of CD31, VE-cad, and SMa via immunoblotting. $n=3$.

Tumors developed from GSCs demonstrate extensive tumor cell-associated vascular channels that are dependent on Flk-1 To determine whether GSCs undergo mural cell differentiation to form tumor vasculature, a process dependent on Flk-1 in vivo, we injected SCID/Beige mice with GSCs expressing control vector carrying either GFP and scramble RNA or Flk-1 shRNA by intracranial transplantation. Mouse survival data indicated that five control GSC-transplanted animals rapidly died from week 6 to week 12 (Fig. 7A). In contrast, only two of five mice receiving Flk-1 shRNA GSCs died between weeks 8 and 10. The remaining three mice lived $>13$ weeks, displaying a trend of longer survival relative to corresponding control mice. Postmortem examination showed that control tumors on the striatum were approximately twofold larger than Flk-1 shRNA tumors (Fig. 7Ba,b). Autoimmunofluorescence studies on control tumor samples showed that scattered GFP-positive tumor cells constituted a porous vascular structure into which blood flow labeled with Evan's Blue dye perfused (Fig. $7 B c, d$ ). But these tumor cell-associated vasculatures in Flk-1 shRNA tumors were barely detectable.

To evaluate whether these vessel cells are mural-like cells derived from GSCs, we used IHC and immunofluorescence approaches. Extensive blood vessels demonstrated strong staining of SMa in control tumors that contained $>1.5$-fold SMa-positive vessels than those in Flk-1 shRNA tumors (Fig. 7C,D). Likewise, PDGFR $\beta$ expression exhibited the same pattern as SMa (Fig. $7 C, D)$. To test the possibility that GSCs may also differentiate into endothelial cells that integrate with preexisting host endothelial cells to participate in angiogenesis, we used anti-CD31 antibodies that individually recognize either mouse or human endothelial cells. None of hCD31-positive vasculature was observed in specimens from either control or Flk-1 shRNA tumors (Fig. 7C), consistent with earlier in vitro results (Fig. 5). In contrast, these tumors contained the same extent of endothelial cell vessels stemmed from mouse vasculature (Fig. 7C,D), implicating that tumor angiogenesis is ascribed to host vessels that may respond to angiogenic factors released from xenografted tumors. Moreover, immunofluorescence analysis unveiled the origin of these differentiated tumor cell-associated vasculatures, as coex- pression of GFP and SMa was identified in the vessels of control tumors, while the costaining was minimal in Flk-1 shRNA samples (Fig. 7Ea,b). But these vessels were distinct from host endothelial cell vessels as demonstrated by separate staining of mCD31 and GFP in the same samples (Fig. $7 E c, d$ ). As noted in the tumor region with a high density of cells, a relatively limited cell population was GFP positive (Fig. $7 B c, d, E a-d$ ). This phenomenon may be attributed to several possibilities such as dampened GFP fluorescence during tissue sectioning, loss of GFP expression in trans/differentiation in vivo, and/or other tumor-infiltrating leukocytes from the host that were deficient of GFP. To further determine whether the Flk-1 gene knockdown suppresses the formation of mural cell-associated vascular channels and/or endothelial cell vessels, we used coimmunofluorescent staining of Flk-1 with either SMa or mCD31. Control tumors showed stronger costaining of Flk-1 with SMa by vascular channels, compared with Flk-1 shRNA tumors that harbored shorter vessels coexpressing weaker Flk-1 and SMa (Fig. 7Ee,f). However, dual staining of Flk-1 with mCD31 did not show a significant difference between control and Flk-1 shRNA tumor vessels, suggesting that Flk-1 gene silencing in mural-like tumor cells inhibits mural cellmediated VM, but not endothelial cell angiogenesis. In sum, all the data demonstrate that mural-like cell transdifferentiation of GSCs mainly participates in tumor cell-associated vascularization, the process dependent on Flk-1, whereas host endothelial cells play a role in tumor angiogenesis.

\section{Discussion}

Recently, several groups have reported that GSCs display the ability to undergo endothelial cell differentiation that participates in tumor angiogenesis (Ricci-Vitiani et al., 2010; Wang et al., 2010). For example, the $\mathrm{CD} 133^{+} / \mathrm{CD} 144^{+}$population derived from GSCs can differentiate into endothelial cells in endothelial cell medium (Wang et al., 2010). This stem cell population transplanted to animals developed vascular endothelium in tumors. Likewise, another group found that $\mathrm{CD} 31^{+}$-sorted GSCs are capable of differentiation into endothelial cells that contribute to tumor angiogenesis (Ricci-Vitiani et al., 2010). Concurrent with 
A
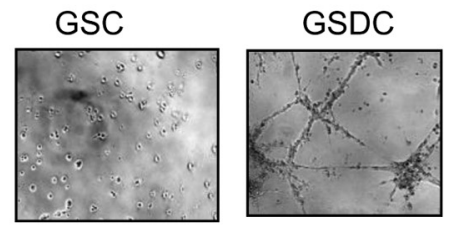

GSDC+DMSO GSDC+SU1498
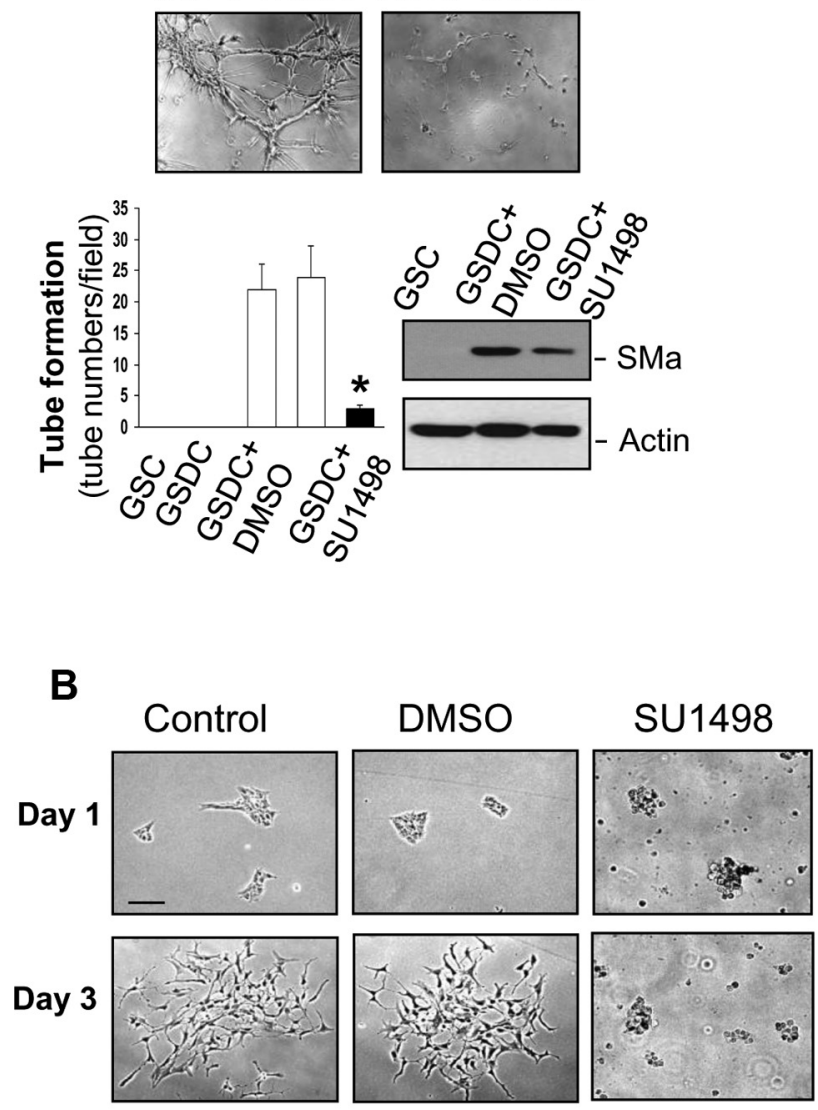

Day 7
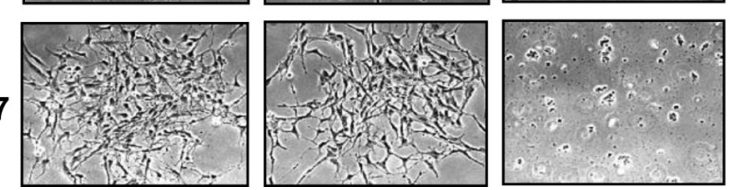

C

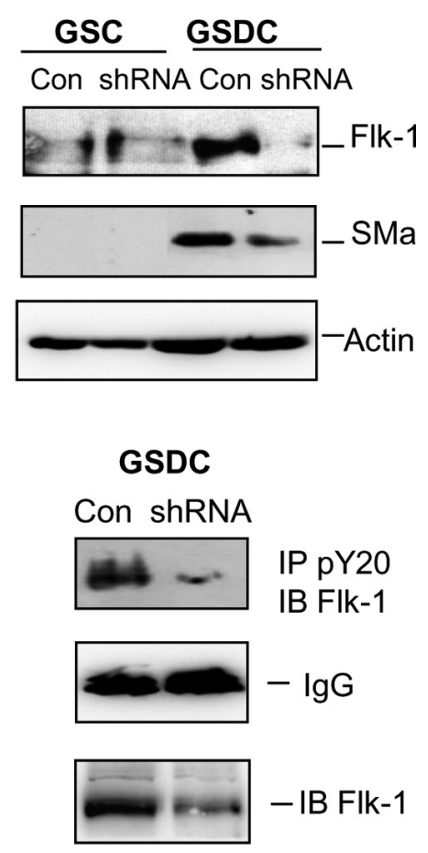

D

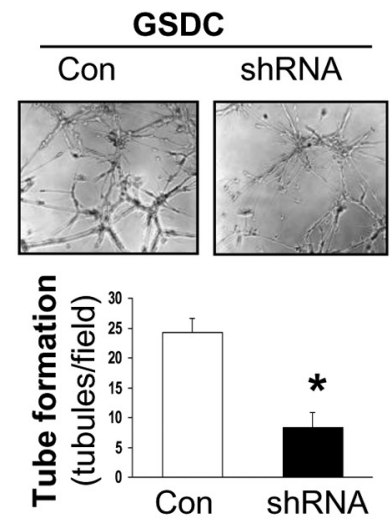

Figure 6. Flk-1 mediates transdifferentiation of GSCS into GSDCs and vascular development. $A$, GSCS or GSDCs were cultured on Matrigel in the presence of SU1498 (12.5 $\mu \mathrm{M})$. Tubules were imaged and quantified. $n=3 .{ }^{*} p<0.05$ compared with GSDCs or GSDCs treated with DMSO. Cell lysates were used for immunoblotting against SMa. $B$, GSCs were grown in $10 \%$ FBS DMEM in the presence of SU1498 $(12.5 \mu \mathrm{m})$ for $7 \mathrm{~d}$. Cell phenotypes were imaged on days 1, 3, and 7. Scale bar, $50 \mu \mathrm{m} . n=3$. C, Flk-1 shRNA or scramble RNA in a GFP vector was engineered into GSCS, and then GSCs were transdifferentiated into GSDCS. Some of cell lysates were collected for immunoblotting and some of GSDCs were immunoprecipitated with a monoclonal anti-phosphorylated tyrosine antibody (pY20) followed by immunoblotting against Flk-1. Normal lgG was used as a control. Some of GSDC lysates used for coimmunoprecipitation were also measured for total Flk-1 by immunoblotting. D, Flk-1 scramble control or shRNA cells were used for tube formation assay. ${ }^{*} p<0.05$ compared with controls. $n=4$. Error bars indicate SEM.

these reports, we also found that a small population of GSCs is able to transdifferentiate into endothelial cells in an endothelial cell milieu. To extend these findings, we identified that murallike cell transdifferentiation of GSCs represents an alternatively vascularized mechanism that mediates tumor cell-associated VM in glioblastomas.

We have adopted a multidisciplinary approach by genetic, pathological, and pharmacological means to characterize GSCderived vascularization. We interestingly found that GSCs primarily undergo mural-like tumor cell transdifferentiation. We have provided substantial evidence to support this finding. First, GSC-transplanted into animals gave rise to a vascularized phenotype that is noticeably composed of mural-like tumor cells, whereas GSC-derived endothelial cells contribute to a small component of vessels. Second, concordant with these in vivo data, a condition for endothelial cell transdifferentiation of GSCs and $\mathrm{CD} 133^{\text {high }}$ GSCs in culture, also yielded a population $<1.5 \%$ that expresses CD31. Third, IHC and immunofluorescence analysis in glioblastomas indicated that extensive microvasculature expressed strong SMa, PDGFR $\beta$, and EGFR without CD31 or VEcad expression, and these channels coexisted with CD31- or CD34-positive vessels. Finally, a small fraction of endothelial cell transdifferentiation was similarly identified in the differentiation of normal NSCs. For instance, only 1.6\% endothelial cells were differentiated from NSCs in $16 \mathrm{~d}$ embryonic mice (Wurmser et al., 2004). Thus, in context with all these findings, our study 
A

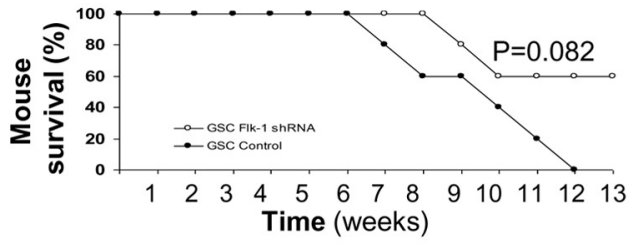

B
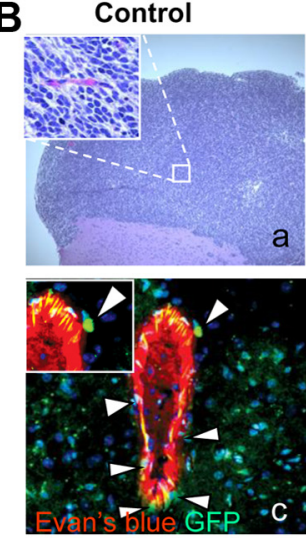

$\mathrm{E}$
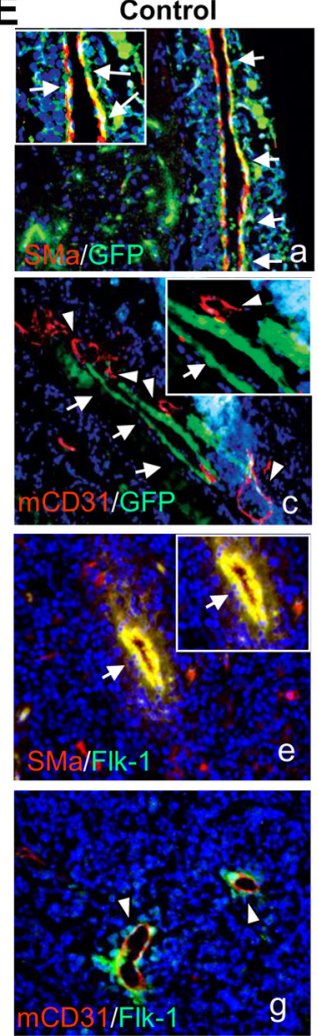

Flk-1 shRNA
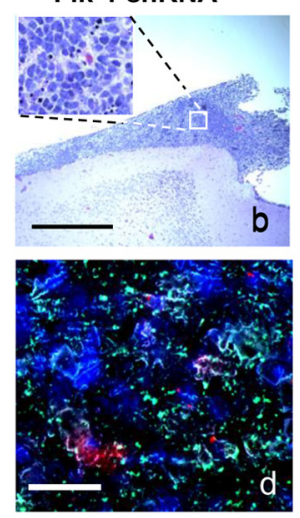

Flk-1 shRNA
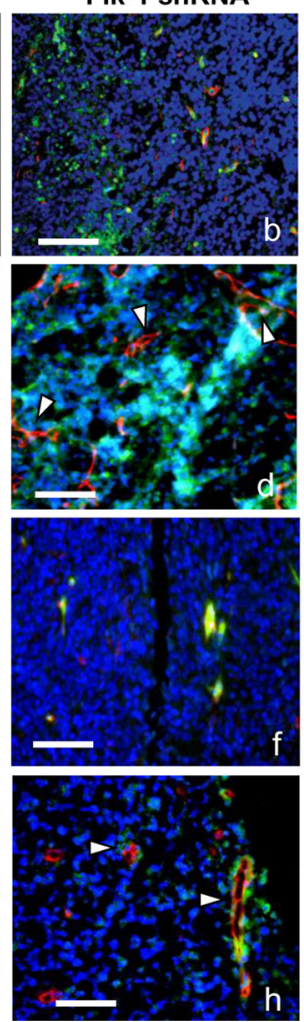

C

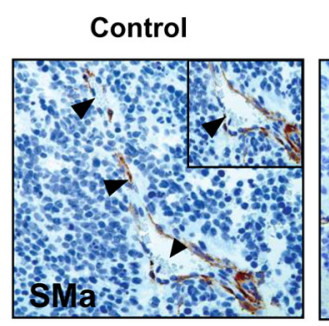

Flk-1 shRNA
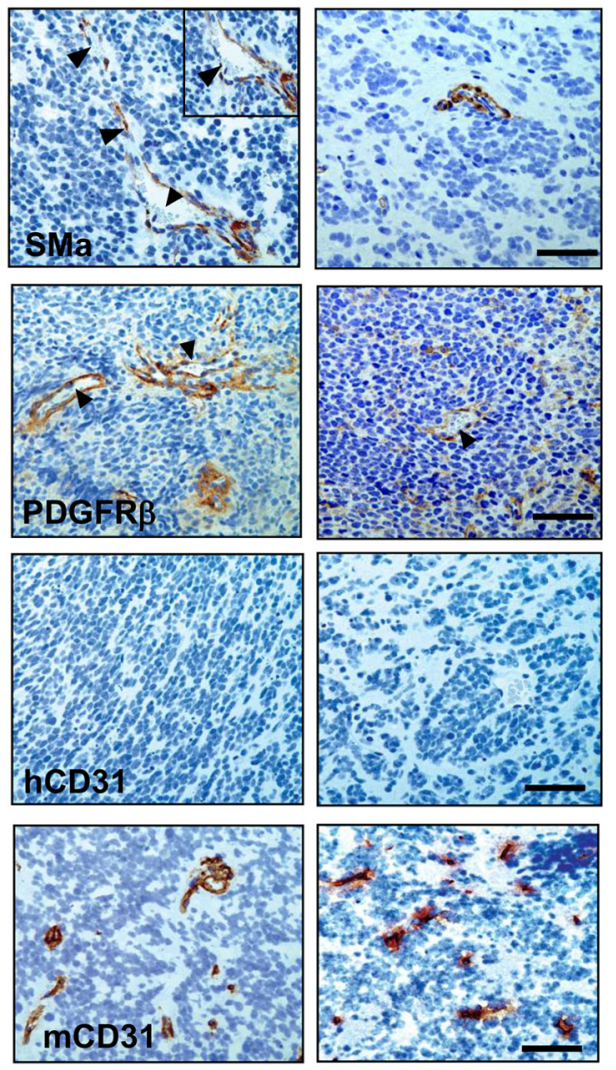

D

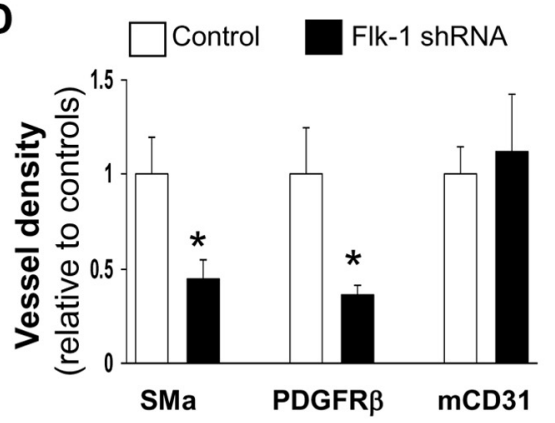

Figure 7. GSCs develop VM in a tumor model, the process dependent on Flk-1.A, GSCs coexpressing scramble RNA or Flk-1 shRNA with GFP were transplanted into mice via intracranial injection, and mouse survival was observed over 13 weeks. $n=5$. B. Twenty minutes before being killed, the mice from both groups were intravenously injected with Evan's Blue dye. Removed brains were processed in coronal sections, and a fragment of the samples was embedded in paraffin for H\&E staining. Tumors were measured for the distance above the striatum in both scramble control and Flk-1 shRNA groups ( $1.84 \pm 0.22$ vs $0.94 \pm 0.19 \mathrm{~mm}$; mean $\pm \mathrm{SE} ; n=5 ; p<0.05)(\boldsymbol{a}, \boldsymbol{b})$. The insets show a magnified field containing tumor cells and vessels. Scale bar, $1.0 \mathrm{~mm}$. Frozen tumor sections from these two groups were evaluated for autofluorescence of GFP (green) and Evan's Blue dye (red). In the control tumors, circulatory vasculature filled with Evan's Blue dye was surrounded by scattered GSCs expressing GFP ( $\boldsymbol{c}$, arrowheads), while weaker Evan's Blue dye was observed in the Flk-1 shRNA tumors (d). Scale bar, $100 \mu$ m. $\boldsymbol{C}$, Tumor samples were subjected to IHC analysis of SMa, PDGFR $\beta, \mathrm{mCD} 31$, and $\mathrm{hCD} 31$. The arrowheads show blood cells in the vessels, and an inset represents a larger image. D, Above vessel density of SMa, PDGFR $\beta$, and $\mathrm{mCD} 31$ was individually quantified compared with corresponding control vessels that were set up with one unit. $n=5 .{ }^{*} p<0.05$ compared with its corresponding controls. Error bars indicate SEM. E, Dual fluorescence of GFP (green autofluorescence) with either SMa $(\boldsymbol{a}, \boldsymbol{b})$ or $\mathrm{mCD} 31(\boldsymbol{c}, \boldsymbol{d})$ (red immunofluorescence), and dual immunofluorescence of Flk- 1 (green) with either SMa $(\boldsymbol{e}, \boldsymbol{f})$ or mCD31 $(\boldsymbol{g}, \boldsymbol{h})(\mathrm{red})$ were analyzed. The arrows indicate mural-like tumor cell-associated vessels coexpressing SMa and GFP (a), GFP only (c), or SMa and Flk-1 (e). The arrowheads depict mouse endothelial cell vessels $(\boldsymbol{c}, \boldsymbol{d}$, $\boldsymbol{g}$, h). The insets show larger images. Scale bars, $100 \mu \mathrm{m}$. 


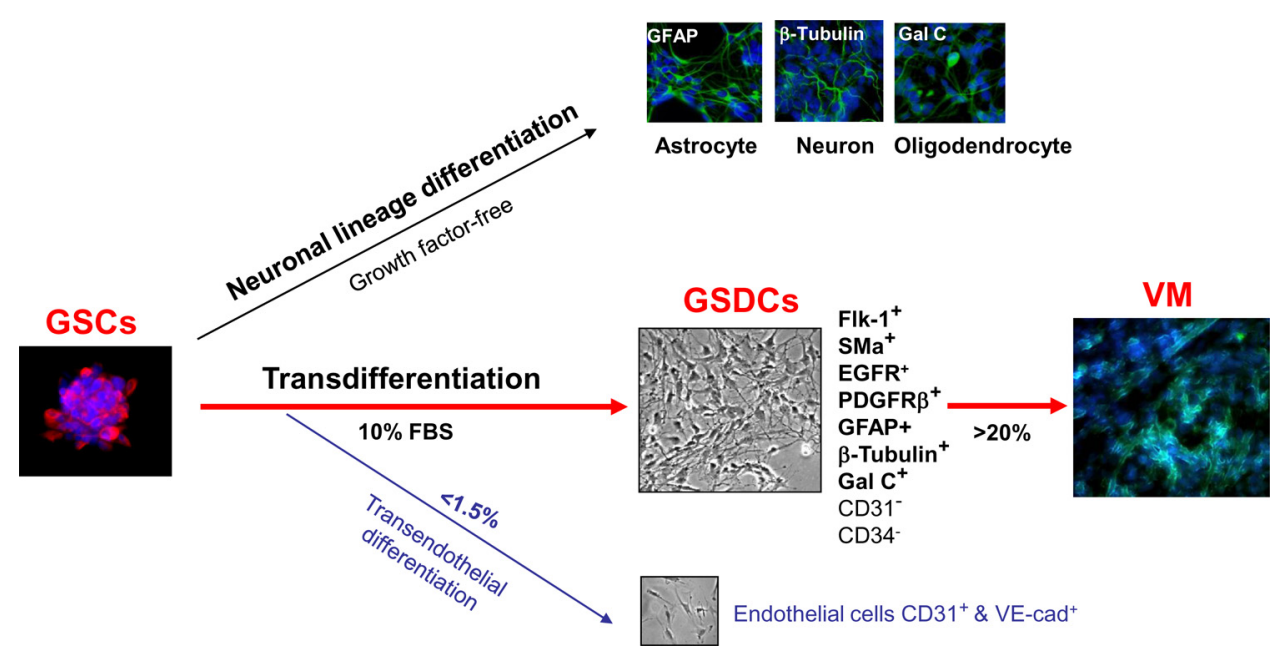

Figure 8. A hypothetical model for GSC differentiation and transdifferentiation. In the presence of 10\% FBS, GSCs undergo transdifferentiation into GSDCS coexpressing Flk-1, SMa, PDGFR $\beta$, EGFR, GFAP, $\beta$-tubulin, Gal C; but not CD31 or CD34, which promotes VM. When GSCS grow in growth factor-free stem cell medium, they are able to differentiate into neural lineages including astrocytes, neurons, and oligodendrocytes. GSCs can also transdifferentiate into vascular endothelial cells that participate in tumor angiogenesis.

demonstrates that GSCs mainly differentiate into mural-like tumor cells to promote VM in glioblastomas. This transdifferentiation of GSCs into mural-like tumor cells highlights the plasticity of GSCs characteristic of both neural tumor cells and vascular wall cells. In addition, this plasticity of GSCs recapitulates the multipotency of NSCs capable of differentiation into several cell lineages distinct from neural cells such as blood cells (Bjornson et al., 1999), muscle cells (Galli et al., 2000), and vascular endothelial cells (Wurmser et al., 2004). A model proposed for GSC differentiation is illustrated in Figure 8.

A wealth of research has demonstrated that the presence of a small population of GSCs is closely associated with resistance to radiotherapy and anti-angiogenic therapy (Kioi et al., 2010). However, clinical regimen using an anti-VEGF therapy alone failed to significantly ameliorate patient overall survival (Verhoeff et al., 2009). It is thus logical to speculate that, as part of its ability to survive in the presence of anti-angiogenic agents and reemerge from dormant primary tumors, GSCs may undergo an alternative vascularization that develops mural-like cellassociated networks and nourishes the bulk of growing tumor cells. Indeed, there is considerable evidence documented to support this hypothesis (Folkins et al., 2009; El Hallani et al., 2010). Interestingly, we found that this vasculature property is independent of CD133 expression in GSCs. But this is not completely unexpected because there is a large body of evidence showing that the population of $\mathrm{CD}_{13} 3^{+}$and $\mathrm{CD} 133^{-}$GSCs equally contribute to glioblastoma malignancy (Phillips et al., 2006; Chen et al., 2010; Prestegarden et al., 2010). Thus, the hierarchy of CD133expressing population is not directly associated with VM unless they undergo differentiation into mural-like tumor cells.

Recently, growing evidence has shown that VM plays a vital role in the vascularization of multiple solid tumors including glioblastomas (Folberg and Maniotis, 2004; Chen et al., 2012). Transdifferentiation of GSCs into smooth muscle-like cells has been implicated in vasculature formation of glioblastomas (El Hallani et al., 2010; Ping and Bian, 2011). However, to date, substantial cellular and molecular mechanisms underlying this pathogenesis of VM in glioblastomas are largely elusive. We have identified that Flk-1 acquired by differentiated GSCs is at least one of the most important factors that govern the process of VM and tumor development, which is consistent with the observation using tumor cell lines in vitro in Flk-1- mediated VM independent of VEGF (Francescone et al., 2012). The current finding of Flk-1 in GSC transdifferentiation is also in line with previous data that Flk-1 has a key role in the transdifferentiation of embryonic stem cells into vascular cells (Yamashita et al., 2000; Yang et al., 2008; Taura et al., 2009). Indeed, there is a clinical trial reporting a promising response to an Flk-1 kinase inhibitor AZD2171 (4-[(4-fluoro-2-methyl-1 H-indol-5-yl)oxy]-6-methoxy7-[3-(pyrrolidin-1-yl)propoxy] quinazoline) in the reduction of tumor vasculature and edema during glioblastoma therapy (Batchelor et al., 2007; Kamoun et al., 2009). Thus, Flk-1 expressed by murallike tumor cells may serve as a new target for glioblastoma therapy. A recent interesting report found that endothelial cell vessel density in VM-positive tumors was lower than that in VM-negative tumors (Liu et al., 2011), suggesting an important component of VM in vascularization in which endothelial cell angiogenesis is minimal. Therefore, a combined antivascular therapy aiming at both murallike tumor cells and endothelial cells, in addition to cytotoxic drugs targeting tumor cells, may hold promise for treatment of this devastating disease.

\section{References}

Batchelor TT, Sorensen AG, di Tomaso E, Zhang WT, Duda DG, Cohen KS, Kozak KR, Cahill DP, Chen PJ, Zhu M, Ancukiewicz M, Mrugala MM, Plotkin S, Drappatz J, Louis DN, Ivy P, Scadden DT, Benner T, Loeffler JS, Wen PY, et al. (2007) AZD2171, a pan-VEGF receptor tyrosine kinase inhibitor, normalizes tumor vasculature and alleviates edema in glioblastoma patients. Cancer Cell 11:83-95.

Beier D, Hau P, Proescholdt M, Lohmeier A, Wischhusen J, Oefner PJ, Aigner L, Brawanski A, Bogdahn U, Beier CP (2007) $\mathrm{CD}_{133^{+}}$and CD133 glioblastoma-derived cancer stem cells show differential growth characteristics and molecular profiles. Cancer Res 67:4010-4015.

Bergers G, Hanahan D (2008) Modes of resistance to anti-angiogenic therapy. Nat Rev Cancer 8:592-603.

Bjornson CR, Rietze RL, Reynolds BA, Magli MC, Vescovi AL (1999) Turning brain into blood: a hematopoietic fate adopted by adult neural stem cells in vivo. Science 283:534-537.

Chang YS, di Tomaso E, McDonald DM, Jones R, Jain RK, Munn LL (2000) Mosaic blood vessels in tumors: frequency of cancer cells in contact with flowing blood. Proc Natl Acad Sci U S A 97:14608-14613.

Chen R, Nishimura MC, Bumbaca SM, Kharbanda S, Forrest WF, Kasman IM, Greve JM, Soriano RH, Gilmour LL, Rivers CS, Modrusan Z, Nacu S, Guerrero S, Edgar KA, Wallin JJ, Lamszus K, Westphal M, Heim S, James CD, VandenBerg SR, et al. (2010) A hierarchy of self-renewing tumorinitiating cell types in glioblastoma. Cancer Cell 17:362-375. 
Chen Y, Jing Z, Luo C, Zhuang M, Xia J, Chen Z, Wang Y (2012) Vasculogenic mimicry-potential target for glioblastoma therapy: an in vitro and in vivo study. Med Oncol 29:324-331.

El Hallani S, Boisselier B, Peglion F, Rousseau A, Colin C, Idbaih A, Marie Y, Mokhtari K, Thomas JL, Eichmann A, Delattre JY, Maniotis AJ, Sanson M (2010) A new alternative mechanism in glioblastoma vascularization: tubular vasculogenic mimicry. Brain 133:973-982.

Feng H, Hu B, Jarzynka MJ, Li Y, Keezer S, Johns TG, Tang CK, Hamilton RL, Vuori K, Nishikawa R, Sarkaria JN, Fenton T, Cheng T, Furnari FB, Cavenee WK, Cheng SY (2012) Phosphorylation of dedicator of cytokinesis 1 (Dock180) at tyrosine residue Y722 by Src family kinases mediates EGFRvIII-driven glioblastoma tumorigenesis. Proc Natl Acad Sci U S A 109:3018-3023.

Folberg R, Maniotis AJ (2004) Vasculogenic mimicry. APMIS 112:508-525. Folberg R, Arbieva Z, Moses J, Hayee A, Sandal T, Kadkol S, Lin AY, ValyiNagy K, Setty S, Leach L, Chévez-Barrios P, Larsen P, Majumdar D, Pe'er J, Maniotis AJ (2006) Tumor cell plasticity in uveal melanoma: microenvironment directed dampening of the invasive and metastatic genotype and phenotype accompanies the generation of vasculogenic mimicry patterns. Am J Pathol 169:1376-1389.

Folkins C, Shaked Y, Man S, Tang T, Lee CR, Zhu Z, Hoffman RM, Kerbel RS (2009) Glioma tumor stem-like cells promote tumor angiogenesis and vasculogenesis via vascular endothelial growth factor and stromal-derived factor 1. Cancer Res 69:7243-7251.

Folkman J (1971) Tumor angiogenesis: therapeutic implications. N Engl J Med 285:1182-1186.

Francescone R, Scully S, Bentley B, Yan W, Taylor SL, Oh D, Moral L, Shao R (2012) Glioblastoma-derived tumor cells induce vasculogenic mimicry through Flk-1 activation. J Biol Chem 287:24821-24831.

Galli R, Borello U, Gritti A, Minasi MG, Bjornson C, Coletta M, Mora M, De Angelis MG, Fiocco R, Cossu G, Vescovi AL (2000) Skeletal myogenic potential of human and mouse neural stem cells. Nat Neurosci 3:986-991.

Galli R, Binda E, Orfanelli U, Cipelletti B, Gritti A, De Vitis S, Fiocco R, Foroni C, Dimeco F, Vescovi A (2004) Isolation and characterization of tumorigenic, stem-like neural precursors from human glioblastoma. Cancer Res 64:7011-7021.

Heimberger AB, Hlatky R, Suki D, Yang D, Weinberg J, Gilbert M, Sawaya R, Aldape K (2005) Prognostic effect of epidermal growth factor receptor and EGFRvIII in glioblastoma multiforme patients. Clin Cancer Res 11:1462-1466.

Hendrix MJ, Seftor EA, Hess AR, Seftor RE (2003) Vasculogenic mimicry and tumour-cell plasticity: lessons from melanoma. Nat Rev Cancer 3:411-421.

Jung CS, Foerch C, Schänzer A, Heck A, Plate KH, Seifert V, Steinmetz H, Raabe A, Sitzer M (2007) Serum GFAP is a diagnostic marker for glioblastoma multiforme. Brain 130:3336-3341.

Kamoun WS, Ley CD, Farrar CT, Duyverman AM, Lahdenranta J, Lacorre DA, Batchelor TT, di Tomaso E, Duda DG, Munn LL, Fukumura D, Sorensen AG, Jain RK (2009) Edema control by cediranib, a vascular endothelial growth factor receptor-targeted kinase inhibitor, prolongs survival despite persistent brain tumor growth in mice. J Clin Oncol 27:2542-2552.

Kioi M, Vogel H, Schultz G, Hoffman RM, Harsh GR, Brown JM (2010) Inhibition of vasculogenesis, but not angiogenesis, prevents the recurrence of glioblastoma after irradiation in mice. J Clin Invest 120:694-705.

Lee J, Kotliarova S, Kotliarov Y, Li A, Su Q, Donin NM, Pastorino S, Purow BW, Christopher N, Zhang W, Park JK, Fine HA (2006) Tumor stem cells derived from glioblastomas cultured in bFGF and EGF more closely mirror the phenotype and genotype of primary tumors than do serumcultured cell lines. Cancer Cell 9:391-403.

Liu XM, Zhang QP, Mu YG, Zhang XH, Sai K, Pang JC, Ng HK, Chen ZP (2011) Clinical significance of vasculogenic mimicry in human gliomas. J Neurooncol 105:173-179.

Maniotis AJ, Folberg R, Hess A, Seftor EA, Gardner LM, Pe'er J, Trent JM, Meltzer PS, Hendrix MJ (1999) Vascular channel formation by human melanoma cells in vivo and in vitro: vasculogenic mimicry. Am J Pathol 155:739-752.

Mischel PS, Shai R, Shi T, Horvath S, Lu KV, Choe G, Seligson D, Kremen TJ, Palotie A, Liau LM, Cloughesy TF, Nelson SF (2003) Identification of molecular subtypes of glioblastoma by gene expression profiling. Oncogene 22:2361-2373.

Oishi K, Kobayashi A, Fujii K, Kanehira D, Ito Y, Uchida MK (2004) Angiogenesis in vitro: vascular tube formation from the differentiation of neural stem cells. J Pharmacol Sci 96:208-218.

Phillips HS, Kharbanda S, Chen R, Forrest WF, Soriano RH, Wu TD, Misra A, Nigro JM, Colman H, Soroceanu L, Williams PM, Modrusan Z, Feuerstein BG, Aldape K (2006) Molecular subclasses of high-grade glioma predict prognosis, delineate a pattern of disease progression, and resemble stages in neurogenesis. Cancer Cell 9:157-173.

Ping YF, Bian XW (2011) Concise review: contribution of cancer stem cells to neovascularization. Stem Cells 29:888-894.

Prestegarden L, Svendsen A, Wang J, Sleire L, Skaftnesmo KO, Bjerkvig R, Yan T, Askland L, Persson A, Sakariassen PØ, Enger PØ (2010) Glioma cell populations grouped by different cell type markers drive brain tumor growth. Cancer Res 70:4274-4279.

Ricci-Vitiani L, Pallini R, Biffoni M, Todaro M, Invernici G, Cenci T, Maira G, Parati EA, Stassi G, Larocca LM, De Maria R (2010) Tumour vascularization via endothelial differentiation of glioblastoma stem-like cells. Nature 468:824-828.

Seftor RE, Seftor EA, Koshikawa N, Meltzer PS, Gardner LM, Bilban M, Stetler-Stevenson WG, Quaranta V, Hendrix MJ (2001) Cooperative interactions of laminin 5 gamma2 chain, matrix metalloproteinase-2, and membrane type-1-matrix/metalloproteinase are required for mimicry of embryonic vasculogenesis by aggressive melanoma. Cancer Res 61:63226327.

Shao R, Hamel K, Petersen L, Cao QJ, Arenas RB, Bigelow C, Bentley B, Yan W (2009) YKL-40, a secreted glycoprotein, promotes tumor angiogenesis. Oncogene 28:4456-4468.

Singh SK, Hawkins C, Clarke ID, Squire JA, Bayani J, Hide T, Henkelman RM, Cusimano MD, Dirks PB (2004) Identification of human brain tumour initiating cells. Nature 432:396-401.

Taura D, Sone M, Homma K, Oyamada N, Takahashi K, Tamura N, Yamanaka S, Nakao K (2009) Induction and isolation of vascular cells from human induced pluripotent stem cells-brief report. Arterioscler Thromb Vasc Biol 29:1100-1103.

Verhoeff JJ, van Tellingen O, Claes A, Stalpers LJ, van Linde ME, Richel DJ, Leenders WP, van Furth WR (2009) Concerns about anti-angiogenic treatment in patients with glioblastoma multiforme. BMC Cancer 9:444.

Wang R, Chadalavada K, Wilshire J, Kowalik U, Hovinga KE, Geber A, Fligelman B, Leversha M, Brennan C, Tabar V (2010) Glioblastoma stem-like cells give rise to tumour endothelium. Nature 468:829-833.

Wen PY, Kesari S (2008) Malignant gliomas in adults. N Engl J Med 359:492-507

Wurmser AE, Nakashima K, Summers RG, Toni N, D'Amour KA, Lie DC, Gage FH (2004) Cell fusion-independent differentiation of neural stem cells to the endothelial lineage. Nature 430:350-356.

Yamashita J, Itoh H, Hirashima M, Ogawa M, Nishikawa S, Yurugi T, Naito M, Nakao K, Nishikawa S (2000) Flk1-positive cells derived from embryonic stem cells serve as vascular progenitors. Nature 408:92-96.

Yan W, Cao QJ, Arenas RB, Bentley B, Shao R (2010) GATA3 inhibits breast cancer metastasis through the reversal of epithelial-mesenchymal transition. J Biol Chem 285:14042-14051.

Yang L, Soonpaa MH, Adler ED, Roepke TK, Kattman SJ, Kennedy M, Henckaerts E, Bonham K, Abbott GW, Linden RM, Field LJ, Keller GM (2008) Human cardiovascular progenitor cells develop from a KDR + embryonic-stem-cell-derived population. Nature 453:524-528.

Zheng H, Ying H, Wiedemeyer R, Yan H, Quayle SN, Ivanova EV, Paik JH, Zhang H, Xiao Y, Perry SR, Hu J, Vinjamoori A, Gan B, Sahin E, Chheda MG, Brennan C, Wang YA, Hahn WC, Chin L, DePinho RA (2010) PLAGL2 regulates Wnt signaling to impede differentiation in neural stem cells and gliomas. Cancer Cell 17:497-509. 